\title{
One new and two little-known species of the millipede family Polydesmidae from southern China (Diplopoda: Polydesmida)
}

\section{Один новый и два малоизвестных вида диплопод семейства Polydesmidae из Южного Китая (Diplopoda: Polydesmida)}

\author{
S.I. Golovatch ${ }^{1}$, Weixin Liu' ${ }^{2}$ Youbang Li ${ }^{3}$, J.-J. Geoffroy ${ }^{4}$ \\ С.И. Головач ${ }^{1}$, Вейшин $\Lambda ю^{2}$, Юбанг $\Lambda и^{3}$, ЖК.-Ж. ЖКоффруа ${ }^{4}$
}

\footnotetext{
${ }^{1}$ Institute for Problems of Ecology and Evolution, Russian Academy of Sciences, Leninsky pr. 33, Moscow 119071, Russia.

${ }^{1}$ Институт проблем экологии и эволюции РАН, Ленинский пр. 33, Москва 119071 Россия.

${ }^{2}$ College of Natural Resources and Environment, South China Agricultural University, Guangzhou City, Guangdong Province 510642, China.

${ }^{3}$ College of Life Science, Guangxi Normal University, Guilin, Guangxi Province 541004, China.

${ }^{4}$ Muséum national d'Histoire naturelle, Département Ecologie \& Gestion de la Biodiversité, UMR 7204 CERSP du CNRS, Equipe EVOLTRAIT, 4, avenue du Petit Château, F-91800 Brunoy, France.
} China.

КЛЮЧЕВЫЕ СЛОВА: Diplopoda, Glenniea, Epanerchodus, таксономия, новый вид, пещера, Гуанси, Гуйчжоу, Китай.

ABSTRACT. The small, basically Himalayan genus Glenniea Turk, 1945 is formally new to the fauna of China due to the discovery of $G$. prima sp.n., a species that lives epigeically in Guangxi Province. Epanerchodus orientalis Attems, 1901, a highly polymorphous species very common in Japan and Taiwan, is formally reported from China for the first time as well, based on a cave population in Guangxi Province. A new cave locality is also presented for E. stylotarseus Chen \& Zhang, 1990, a species already known from three other caves in the same Guanling County, Guizhou Province.

РЕЗЮМЕ. Небольшой, в основном гималайский род Glenniea Turk, 1945 - формально новый для фауны Китая, благодаря находке G. prima sp.n., живущей в лесной подстилке в провинции Гуанси. Epanerchodus orientalis Attems, 1901, крайне полиморфный вид, очень обычный в Японии и на Тайване, формально тоже впервые зарегистрирован в Китае, благодаря находке пещерной популяции в провинции Гуанси. Дана новая находка в пещере вида E. stylotarseus Chen \& Zhang, 1990, который до сих пор был известен из других трех пещер в том же районе Гуанлин в провинции Гуйчжоу.

\section{Introduction}

The millipede family Polydesmidae is currently known as being represented in China by species of only three genera: Epanerchodus Attems, 1901 (= Usbekodesmus Lohmander, 1932, synonymized by Golo- vatch et al. [2011]), Polydesmus Latreille, 1803 and Pacidesmus Golovatch, 1991. Epanerchodus is by far the largest polydesmid genus in eastern Asia, counting about 60 nominal species ranging from Central Asia and the Russian Far East in the north to the Himalaya and southern China in the south; yet only eight unquestioned species have hitherto been described or reported from China [Geoffroy \& Golovatch, 2004; Golovatch et al., 2006]. Polydesmus is a huge, basically Mediterranean genus encompassing over 80 species or subspecies, but only a handful are known from Japan, China and Vietnam, including $P$. liber Golovatch, 1991 from Hong Kong [Golovatch, 1991]. There are a few more species from China (and Japan) which are still formally assigned to Polydesmus, but, since they were described from females, their identities remain obscure (see review by Golovatch [1991]). Pacidesmus is a fairly small genus which currently includes only seven species, of which six occur solely in caves in southern China [Golovatch et al., 2010].

Prompted by the recent discovery of an unusual new polydesmid in Guangxi and one each poorly-known species in Guangxi and Guizhou provinces, southern China, we put these novelties on record in the present paper. The new species appears to belong to a genus reported from China for the first time, and one more is a species new to the Chinese list. The holotype will be deposited in the collection of the Institute of Zoology, Chinese Academy of Sciences, Beijing, China (IZAS), whereas non-type duplicates will be shared between the collections of the South China Agricultural University, Guangzhou, China (SCAU), Guangxi Normal Uni- 
versity, Guilin, China (GNUG), Zoological Museum, University of Moscow, Russia (ZMUM), and Muséum national d'Histoire naturelle, Paris, France (MNHN).

\section{Taxonomic part}

Epanerchodus orientalis Attems, 1901

Figs 1-9.

MATERIAL. $1 \sigma^{7}$ (IZAS), $1 \sigma^{7}$ (GNUG), $1 \sigma^{7}$ (MNHN JC 133), $10^{7}$ (ZMUM), 1 ㅇ (SCAU), China, Guangxi Prov., Fuchuan County, Bainiu, Cave Banbianshan Dong, 25.01.2012, leg. Li Youbang, Li Youting and Tang Kewen (CHIgx12-LYB06).

REDESCRIPTION. Regardless of sex, length 10 $17 \mathrm{~mm}$, width of their midbody pro- and metazona 1.4 and 1.9 to 1.8 and $2.5 \mathrm{~mm}$, respectively. Coloration in alcohol mostly uniformly pallid (Figs $1-4$ ), only rarely front part of body, including antennae, faintly pinkish.

Body with 20 segments. Head very densely pilose, only vertex nearly bare; epicranial suture distinct. Antennae short and stout (Fig. 1), overreaching segment 3 dorsally; antennomere 3 longest; antennomere 7 with an evident dorsoparabasal cone. In width, collum < head $=$ segment $2<3=4<5=17$, thereafter body gently tapering towards telson. Paraterga rather strongly developed (Figs 2-4), upturned starting from collum, ending above level of dorsum on collum and following segments 2-4, level to dorsum and subhorizontal until segment 17 , slightly below dorsum thereafter. Starting from segment 4, paraterga increasingly well protruded behind rear tergal margin, caudal tips very narrowly rounded to pointed. Paraterga with two rows of small, but evident bosses, $2+2$ and $4+4$, respectively. Paraterga of collum and paraterga 2-4 with an evident indentation at margin in front of caudal corner; subsequent poreless paraterga each with three, all pore-bearing paraterga with four, increasingly poorly developed indentations at lateral margin. Front margin slightly rebordered and upturned, in paraterga 2-4 very faintly convex, nearly straight, thereafter first subrectangular, then increasingly obtusangular, more convex, forming a distinct shoulder with anterior indentation at lateral margin until segment 19 , on $19^{\text {th }}$ broadly rounded. Pore formula normal, ozopores evident, dorsolateral, located just behind $4^{\text {th }}$ indentation. Metatergal sculpture typical, with three transverse rows of setiferous bosses: bosses in anterior row especially large, polygonal, paramedian $2+2$ a little higher; those in both middle and posterior rows much smaller, paramedian $2+2$ and $2+2$ also a little higher; anterior one set off by a vague transverse sulcus. Surface of prozona, of metaterga below paraterga and of stricture between pro- and metazona finely shagreened and alveolate, poorly shining; only metaterga, albeit with same texture, more evidently shining due to smooth bosses in middle and posterior rows, as well as to paraterga. Tergal setae very short, pointed, partly retained only on collum. Very small pleurosternal carinae present only on segment 2 . Epiproct short, conical. Hypoproct roundly subtrapeziform; caudal, paramedian, setiferous papillae very long and only rather slightly separated.

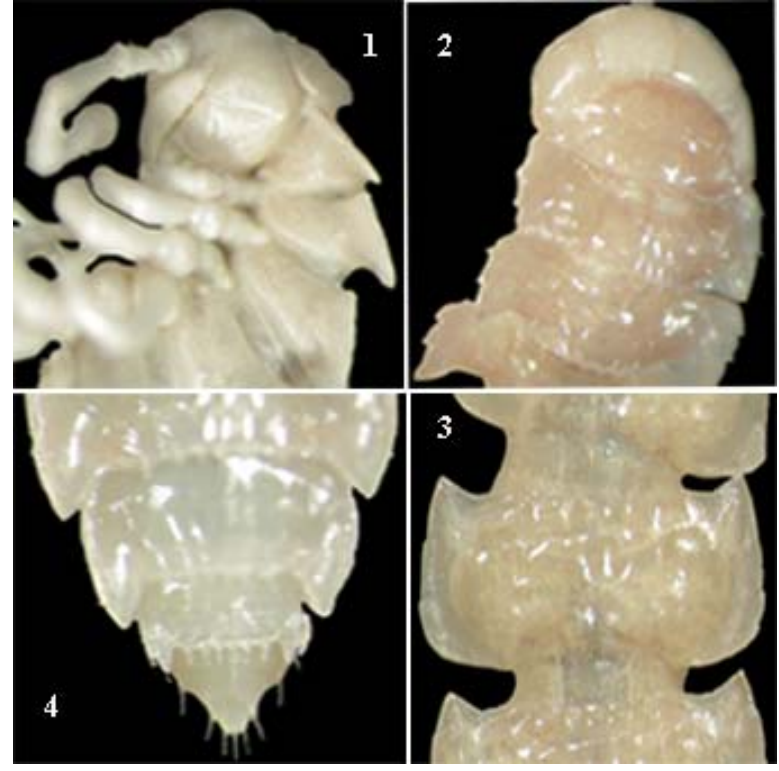

Figs 1-4. Epanerchodus orientalis Attems, 1901, О7. 1 \& 2 anterior body portion, lateral and dorsal views, respectively; 3 midbody segments, dorsal view; 4 - posterior body portion, dorsal view. Photographed not to scale.

Рис. 1-4. Epanerchodus orientalis Attems, 1901, О7. 1, 2 передняя часть тела, соответственно сбоку и сверху; 3 - среднетуловищные сегменты, сверху; 4 - задняя часть тела, сверху. Сфотографировано без масштаба.

Sterna without modifications, modestly setose; cross-impressions evident. Legs rather long and slender (Fig. 5), evidently incrassate in $\sigma^{\top}$, ca 2.2 times as long as midbody height; sphaerotrichomes well visible on virtually all telopoditomeres.

Gonopods (Figs 6-9) in two dissected $\sigma^{7} \sigma^{7}$ strongly different, but showing all basic elements characteristic of E. orientalis. Coxa with two distodorsal macrochaetae. Exomere (a) very simple, short to very short. Both branches of endomere (b and $\mathbf{c}$ ) very prominent (Figs 6 \& 7) to moderately well-developed, especially c (Figs 8 \& 9), sometimes with a small subtriangular lobule (I) at base in-between. Seminal groove typical of the genus, starting on mesal face to rather rapidly move onto lateral side between $\mathbf{a}$ and $\mathbf{b}$, continuing there at bottom of a distinct or rather distinct cavity to finally enter a well-developed accessory seminal chamber; the latter opening with a clear-cut hairy pulvillus.

REMARKS. As the above redescription shows, there are virtually no characters that would allow us to clearly distinguish the above material from the known diagnoses of E. orientalis, a widespread East Asian species with several suspected synonymies still to be verified [e.g. Golovatch et al., 2010]. Based on the quite ordinary appearance of this population, we are inclined to consider it as troglophilic at most. In Japan, some more populations are known to occur in caves as well, but basically $E$. orientalis is largely an epigean species, in many places likely anthropochore; it has already been noted as probably the most widespread and polymor- 

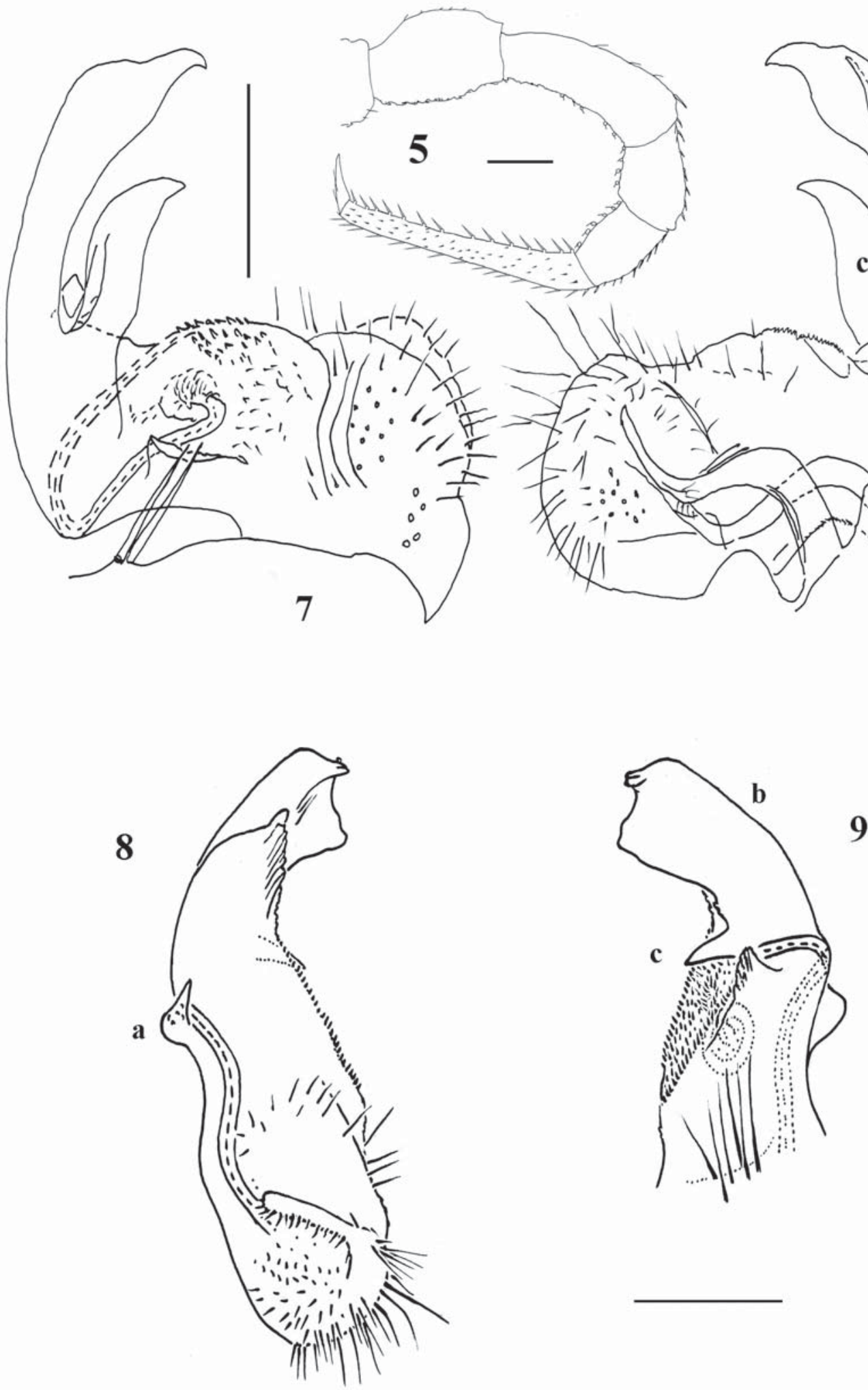

Figs 5-9. Epanerchodus orientalis Attems, 1901, O $0^{7} 0^{7} .5$ - midbody leg, caudal view; 6 \& 7 - right gonopod, mesal and lateral views, respectively; $8 \& 9$ - left gonopod, mesal and lateral views, respectively. Scale bars: 0.25 (5) \& $0.2 \mathrm{~mm}(6-9)$.

Рис. 5-9. Epanerchodus orientalis Attems, 1901, О7 $\sigma^{7} .5$ - среднетуловищная нога, сзади; 6, 7 - правый гонопод, соответственно изнутри и сбоку; 8, 9 - левый гонопод, соответственно изнутри и сбоку. Масштаб: 0,25 (5), 0,2 мм (6-9). 

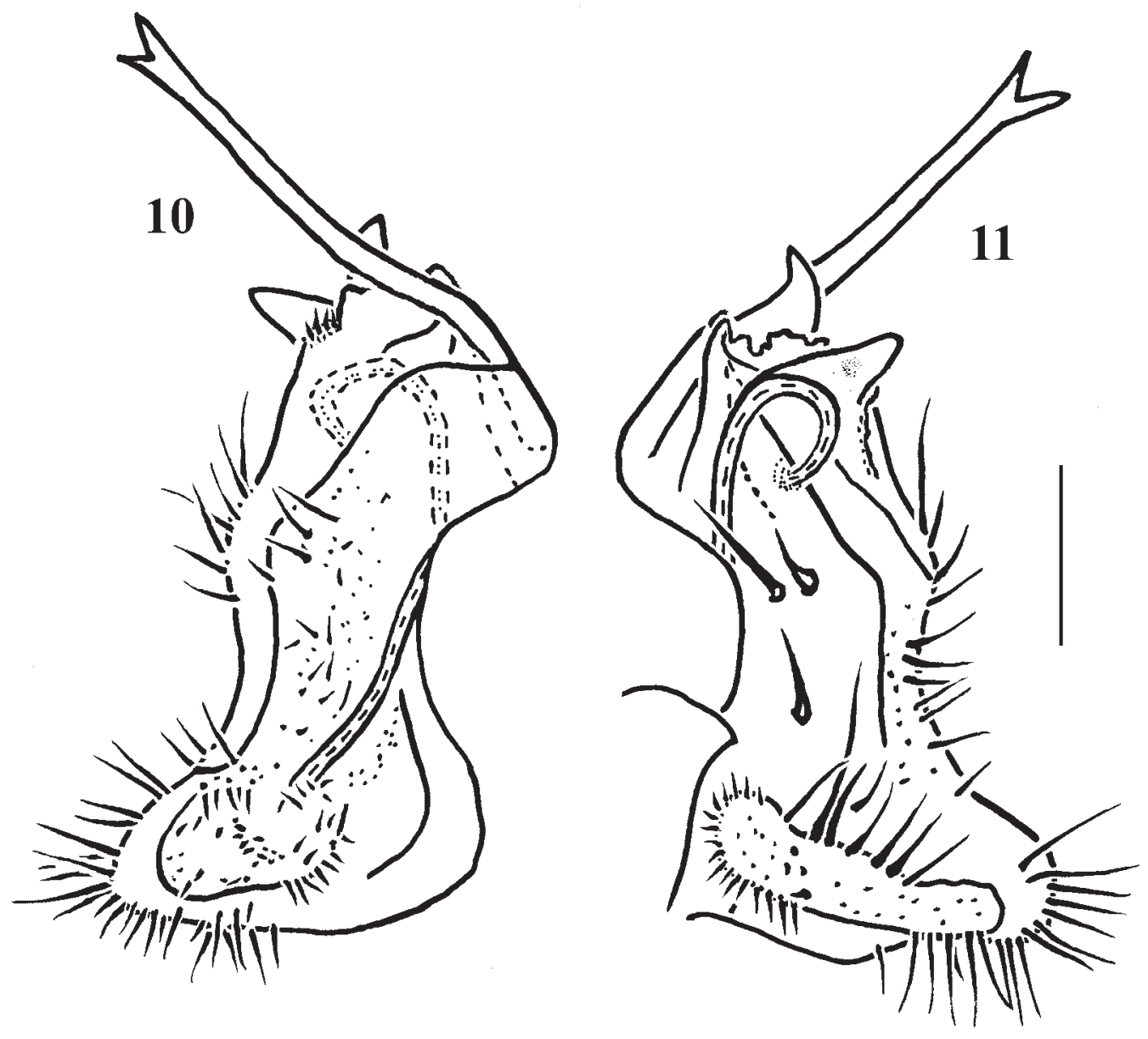

Figs 10 \& 11. Right gonopod of Epanerchodus stylotarseus Chen \& Zhang, 1990, ơ from Cave Jiang Jia Da Dong, mesal and lateral views, respectively. Scale bar: $0.2 \mathrm{~mm}$.

Рис. 10-11. Правый гонопод Epanerchodus stylotarseus Chen \& Zhang, 1990, О7 из пещеры Jiang Jia Da Dong, соответственно изнутри и сбоку. Масштаб: 0,2 мм.

phous among congeners [Golovatch et al., 2010]. It lives almost all over Japan, yet leaving a considerable gap in Kyushu and the Ryukyus before reappearing in Taiwan. It always shows pronounced variation in gonopod traits, as well as some peripheral characters (coloration, height and breadth of paraterga, distribution of sphaerotrichomes etc.). This variation has been documented as being mostly individual at least in Taiwan [Golovatch et al., 2010]. The same obviously concerns the Guangxi population, in which the gonopods differ quite considerably from one male to another (cf. Figs $6 \& 7$ and $8 \& 9$ ).

Before more material has been accumulated from China and elsewhere, especially as regards molecular data, we refer the Chinese cave population to E. orientalis. We simply provide its redescription and illustrations to assist further studies on this taxonomically confusing species. Only genetic investigations are deemed to be capable of ultimately solving the riddle concerning the true identity and range, both morphological and geographic, of E. orientalis.

Epanerchodus stylotarseus Chen \& Zhang, 1990 Figs $10 \& 11$.

MATERIAL. $3 \sigma^{7} \sigma^{7}, 3$ 우 (SCAU), China Guizhou Prov., Guanling County, Cave Jiang Jia Da Dong, 20.07.2009, leg. Zhihong Xue \& Chuanchang Chen (CHIgz09-LWX09).

REMARKS. The above material is in good agreement with the original description by Chen \& Zhang [1990]. New drawings of a gonopod are presented (Figs $10 \& 11$ ) to document the identification. This species has been known from three caves (Cave Gan-zi Dong, Cave Yin Jia Dong 2 and Cave San Ge Dong) in Guanling Bouyeizu Miazu Autonomous County, Guizhou Province, China [Chen \& Zhang, 1990; Golovatch et al., 2006], while the new samples come just from another cave in the same county. 
Glenniea prima sp.n.

Figs $12-17$.

MATERIAL. Holotype $0^{7}$ (IZAS), China, Guangxi Prov., Longzhou City, Nonggang Natural Reserve forest, pass on karst, soil, 16.04.2010, leg. L. Deharveng \& A. Bedos (CHIgx10-24).

DIAGNOSIS. Comes out as G. perarmata Golovatch, 1988, from Bhutan, in the key [Golovatch, 1988], but differs readily from all congeners by its much larger size ( $>7 \mathrm{~mm}$ versus $4.5 \mathrm{~mm}$ in length), but narrower paraterga $(0.6 \mathrm{~mm}$ versus $0.8 \mathrm{~mm})$, by the shape of the paraterga (caudal corner invariably acute and protruding behind rear tergal margin versus neither acute nor protruding behind rear tergal margin), the presence of sphaerotrichomes (versus absent), as well as by the peculiar gonopod structure showing a deeply bipartite and strongly ornamented telopodite.

NAME. To emphasize the first species of Glenniea to be reported from China.

DESCRIPTION. Length ca $7 \mathrm{~mm}$ (incomplete, with 17 segments, the last ?two segments being missing), width 0.4 and $0.6 \mathrm{~mm}$ on midbody pro- and metazona, respectively. Coloration uniformly pallid (Figs 12-15). Head densely pilose. Antennae rather long and evidently clavate (Fig. 12), reaching the end of segment 3 dorsally, with typical distodorsal groups of bacilliform sensilla on antennomeres 5 and 6 , and a minute dorso-parabasal knob on antennomere 7.

In width, collum $<<$ head $<$ segment $2=4<5=17$. Tergal and sternal surface evidently granulate-tuberculate, but shining. Collum rounded anteriorly, acute laterally, straight at base. Metatergal sculpture distinct, represented by usual three transverse rows of setigerous tubercles/bosses, metaterga very slightly convex (Figs 14 \& 15). Tergal setae simple, long, considerably longer on collum, only slightly shorter on metatergum 2 (Figs 12-15). Paraterga poorly developed, lying clearly below level of dorsum (Figs $12 \& 14$ ). Each of poreless paraterga with three, each of pore-bearing ones with four, evident setigerous indentations. Front corner of paraterga largely roundly obtusangular, lateral edge slightly convex, caudal corner invariably acute and protruding behind rear tergal margin (Figs 13 \& 15). Ozopores lying dorsally near last indentation (Fig. 15). Limbus irregularly microdentate.

Pleurotergal carinae absent. Sterna without modifications. Legs rather long and obviously incrassate, in midbody part ca 1.8 times as long as body height. Prefemora not bulged laterally. Sphaerotrichomes welldeveloped, present only on tarsi.

Gonopods (Figs 16 \& 17) highly complex. Coxae evidently micropapillate and poorly setose ventrally. Telopodite clearly bipartite, both branches representing an endomere, both forming a nearly circular structure without traces of an exomere; clivus (c) margin beset with subbacilli- to dentiform structures extending until base of a long, digitiform, caudoventral process (p) similarly ornamented at dorsal edge. Main, frontoventral branch (b) with two distinct lobules (d and e) and, distally, with a number of spinules at ventral edge. A

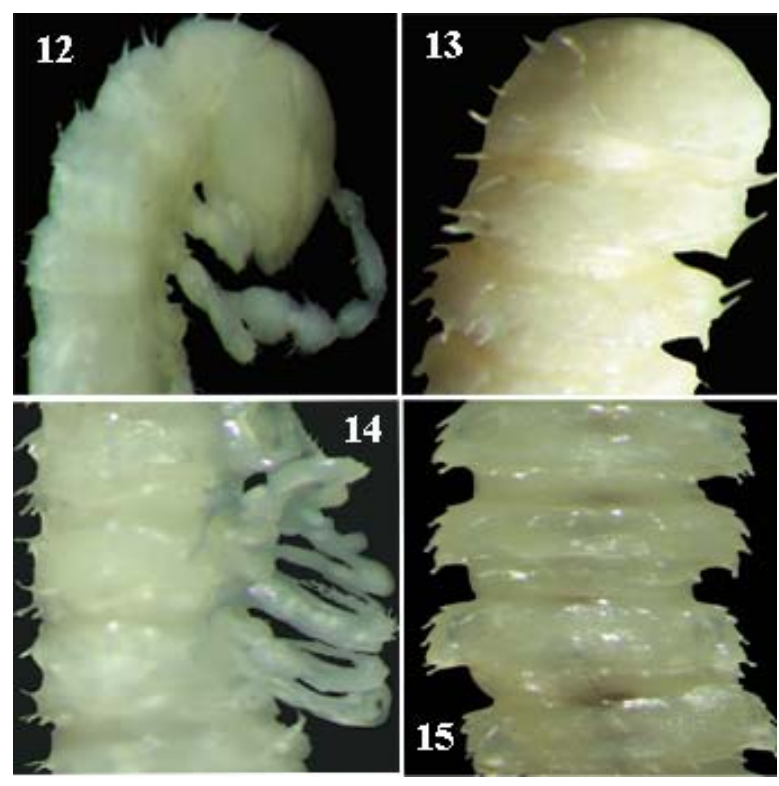

Figs 12-15. Glenniea prima sp.n., $\sigma^{\top}$ holotype. $12 \& 13-$ anterior body portion, lateral and dorsal views, respectively; $14 \&$ 15 - midbody segments, lateral and dorsal views, respectively. Photographed not to scale.

Рис. 12-15. Glenniea prima sp.n., голотип О7. 12, $13-$ передняя часть тела, соответственно сбоку и сверху; 14, 15 среднетуловищные сегменты, соответственно сбоку и сверху. Сфотографировано без масштаба.

small, complex, folded outgrowth (o) near pulvillus. Seminal groove in about basal half running on mesal face, then turning laterad to make a retrorse loop before debauching into a well-developed accessory seminal chamber.

REMARKS. The genus Glenniea Turk, 1945 has hitherto been known to comprise only five valid species, all keyed, and all confined to the Himalaya of India (Kumaon), Nepal and Bhutan [Golovatch, 1987, 1988].

The present discovery of G. prima sp.n. in Guangxi Province, southern China provides a very important range extension for the entire genus far to the east, also representing the first formal record of Glenniea in China. There can hardly be any doubt that more congeners will be revealed with further progress in collecting and studying millipedes in China.

ACKNOWLEDGEMENTS. We are most grateful to Louis Deharveng and Anne Bedos (both MNHN, Paris, France) for the supervision and facilities they provided for accomplishing the present work. It was also sponsored by the World Bank GEF through the financed project "Guangxi integrated forestry development and conservation". Special thanks go to the MNHN administration for financing the first author's stay in Paris in March and April 2012.

\section{References}

Chen Jian-xiu, Zhang Chong-zhou. 1990. A cave-dwelling new species of the diplopod genus Epanerchodus from Guizhou Province (Polydesmida: Polydesmidae) // Acta Zootaxonomica 

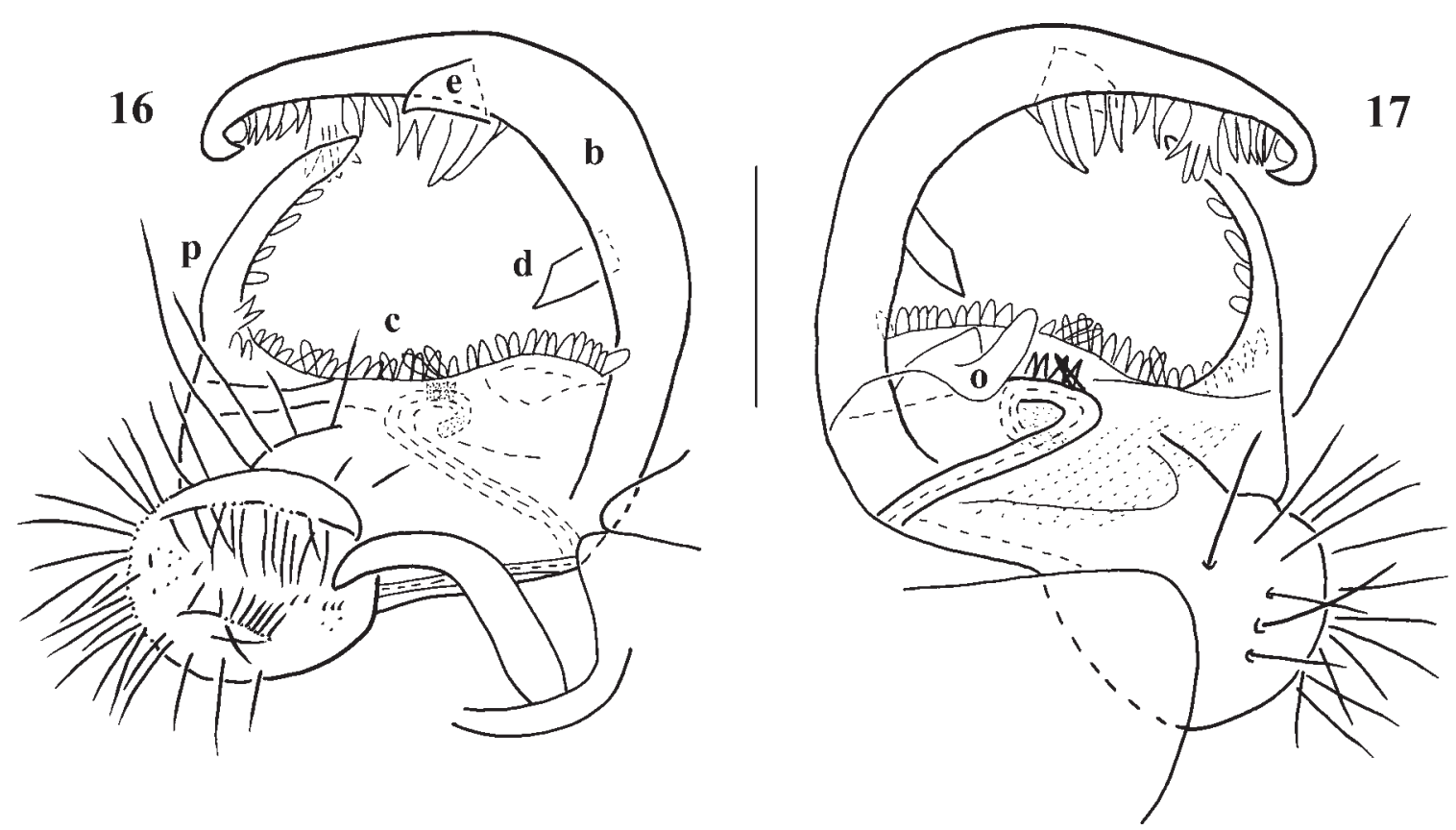

Figs 16 \& 17. Right gonopod of Glenniea prima sp.n., $O^{7}$ holotype, mesal and lateral views, respectively. Scale bar: $0.2 \mathrm{~mm}$. Рис. 16-17. Правый гонопод Glenniea prima sp.n., голотип О’, соответственно изнутри и сбоку. Масштаб: 0,2 мм.

Sinica. Vol.15. No.4. P.406-409 [in Chinese, English summary].

Geoffroy J.-J., Golovatch S.I. 2004. Some polydesmidan millipedes from caves in southern China (Diplopoda: Polydesmida), with descriptions of four new species // Arthropoda Selecta. Vol.13. Nos 1-2. P.19-28.

Golovatch S.I. 1987. Diplopoda from Nepal Himalayas: Glomeridae, additional Opisotretidae // Courier Forschungsinstitut Senckenberg. Bd.93. S.219-228.

Golovatch S.I. 1988. On the first Polydesmidae, Opisotretidae and Fuhrmannodesmidae from Bhutan (Diplopoda, Polydesmida) // Entomologica Basiliensia. Vol.12. P.15-48.

Golovatch S.I. 1991. The millipede family Polydesmidae in Southeast Asia, with notes on phylogeny (Diplopoda: Polydesmida) // Steenstrupia. Vol.17. No.4. P.141-159.
Golovatch S.I., Geoffroy J.-J., Mauriès J.-P. 2006. Several new or poorly-known cavernicolous millipedes (Diplopoda) from southern China // Arthropoda Selecta. Vol.15. No.2. P.81-89.

Golovatch S.I., Geoffroy J.-J., Mauriès J.-P. 2010. Review of the millipede genus Pacidesmus Golovatch, 1991, with descriptions of three new species from caves in southern China (Diplopoda: Polydesmida: Polydesmidae) // Tropical Natural History. Vol.10. No.2. P.159-169.

Golovatch S.I., Mikhaljova E.V., Chang H.W. 2011. The millipede family Polydesmidae in Taiwan, with descriptions of five new species (Polydesmida, Diplopoda) // ZooKeys. Vol.93. P.9-42.

Responsible editor K.G. Mikhailov 